\title{
The effect of alcoholic beverages on iron and zinc metabolism in the rat
}

\author{
BY SUSAN J. FAIR WEATHER-TAIT, SUSAN SOUTHON \\ AND ZOE PIPER
}

\author{
AFRC Institute of Food Research, Colney Lane, Norwich NR4 7UA
}

(Received 29 December 1987 - Accepted 19 April 1988)

\begin{abstract}
1. Male Wistar rats (approximately $200 \mathrm{~g}$ ) were given distilled water and a semi-synthetic control diet for $6 \mathrm{~d}$. On day $7,37 \mathrm{kBq}{ }^{65} \mathrm{Zn}$ were administered intramuscularly and the rats were given distilled water, beer, cider, red wine, whisky or ethanol as their only source of fluid. The wine, whisky and ethanol were diluted so that each of the beverages contained a similar ethanol concentration (approximately $30 \mathrm{~g} / \mathrm{l}$ ). Food and fluid intake, growth rate and whole-body ${ }^{55} \mathrm{Zn}$ were measured regularly over $11 \mathrm{~d}$, after which animals were killed and blood haemoglobin $(\mathrm{Hb})$ concentration, liver iron stores and the $\mathrm{Zn}$ concentration in testes determined.

2. There were no differences in body-weight gain or food intake between groups but fluid intake for the beer group was considerably higher than that for the other groups.

3. There was a significant effect of the type of alcoholic beverage consumed on whole-body ${ }^{65} \mathrm{Zn}$ retention. Rats given whisky had a smaller daily loss of ${ }^{65} \mathrm{Zn}$ than those given water, beer or cider. The ethanol group also showed a lower rate of ${ }^{65} \mathrm{Zn}$ loss compared with the water group. The observed changes in whole-body ${ }^{65} \mathrm{Zn}$ retention could be explained by an adverse influence of ethanol on $\mathrm{Zn}$ absorption from the diet.

4. Blood $\mathrm{Hb}$ and testes $\mathrm{Zn}$ concentration were similar in all groups but the type of liquid consumed influenced liver $\mathrm{Fe}$ levels. The cider group had the lowest liver Fe values and the ethanol group the highest values.

5. It is apparent from the present study that ethanol and alcoholic beverages affect $\mathrm{Zn}$ and Fe metabolism, but that the effects of ethanol are moderated by other components of the alcoholic beverages.
\end{abstract}

Alcohol has been reported to enhance iron absorption, and there appears to be a good correlation between hepatic Fe levels and consumption of alcoholic beverages. Conversely, it has been demonstrated that alcohol increases urinary zinc excretion, which has led to the suggestion that a high intake of alcohol might lead to $\mathrm{Zn}$ deficiency. There may be differences in response depending on the composition of the alcoholic beverage, which are not necessarily the same as the response elicited by ethanol alone (McDonald \& Margen, 1980).

The present study was designed to examine the effects of consuming alcoholic beverages, of similar (modest) ethanol concentration, on $\mathrm{Fe}$ and $\mathrm{Zn}$ status in the rat. A variety of beverages were given in order that direct comparisons between different sources of ethanol could be made. The rate of loss of endogenous $\mathrm{Zn}$ during the period of ethanol ingestion was also measured, using ${ }^{65} \mathrm{Zn}$ to label the metabolically active pool of $\mathrm{Zn}$ in the body, to see whether the alcoholic beverages influenced whole-body $\mathrm{Zn}$ turnover.

\section{MATERIALS AND METHODS}

Sixty immature male Wistar rats were individually caged in stainless-steel and plastic cages with wire-gridded bottoms, and given drinking water and semi-synthetic control diet ad lib. for $6 \mathrm{~d}$. The composition of the diet is given in Table 1. On the 7th day, between 10.00 and 12.00 hours, each animal was given an intramuscular injection containing $37 \mathrm{kBq}^{65} \mathrm{Zn}$ (as zinc chloride; Amersham International plc, Amersham, Bucks.) and then counted in a small-animal whole-body counter (NE8112; NE Technology Ltd, Beenham, Berks), as described previously (Fairweather-Tait \& Wright, 1984). The counting efficiency for ${ }^{65} \mathrm{Zn}$ was approximately $25 \%$. 
Table 1. Composition of the semi-synthetic diet given to rats $(\mathrm{g} / \mathrm{kg}$ diet $)$

\begin{tabular}{lr}
\hline \hline & 309 \\
Maize starch & 309 \\
Sucrose & 200 \\
Casein & 40 \\
Solka floc & 80 \\
Maize oil & 40 \\
Mineral mix & 20 \\
Vitamin mix $\dagger$ & $2 \cdot 5$ \\
\hline
\end{tabular}

* Contained (g/kg diet): $\mathrm{CaHPO}_{4} 13 \cdot 0, \mathrm{Na}_{2} \mathrm{HPO}_{4} 7 \cdot 4, \mathrm{CaCO}_{3} 8 \cdot 2, \mathrm{KCl} 7 \cdot 03, \mathrm{MgSO}_{4} \cdot \mathrm{H}_{2} \mathrm{O} 4 \cdot 0, \mathrm{ZnCO}_{3} 0 \cdot 100$, $\mathrm{FeSO}_{4} .7 \mathrm{H}_{2} \mathrm{O} 0 \cdot 144, \mathrm{CuSO}_{4} .5 \mathrm{H}_{2} \mathrm{O} 0 \cdot 023, \mathrm{KIO}_{3} 0 \cdot 001, \mathrm{MnSO}_{4} \cdot \mathrm{H}_{2} \mathrm{O} 0 \cdot 180$.

$\dagger$ Contained (mg/kg diet): nicotinic acid 60, cyanocobalamin in mannitol (Glaxo) 50, calcium-D-pantothenate 40 , thiamin hydrochloride 10 , riboflavin 10 , pyridoxine 10 , pteroylmonoglutamic acid 10 , D-biotin 1 , vitamin $\mathrm{K}_{1}$ 2, Rovimix E-50 (Roche, North Dunstable, Bedfordshire) 150, Rovimix A-500 25, Rovimix $\mathrm{D}_{3}-500$ 15, choline bitartrate 180 .

The rats were randomly allocated to six groups of ten, and animals in each group given one of the following liquids containing approximately $30 \mathrm{~g}$ alcohol $/ 1$ in place of drinking water as their only source of fluid: group 1, distilled water; group 2, beer (Bentley's Yorkshire Bitter; Whitbread \& Co., London); group 3, cider (Taunton Special Vat Cider; Taunton Cider Co. Ltd, Norton Fitzwarren, Somerset); group 4, diluted red wine (wine-water $0.33: 1, \mathrm{v} / \mathrm{v}$, Colman's French Red Wine, $11.5 \%$ alcohol by volume; Colman's of Norwich, Norfolk); group 5, diluted whisky (whisky-water 0.1:1, v/v, Claymore, $40 \%$ alcohol by volume; A. Ferguson \& Co. Ltd., Glasgow); group 6, diluted ethanol (ethanol-water $0.034: 1, \mathrm{v} / \mathrm{v}$ ). The animals were allowed access to food and drink ad lib. for $11 \mathrm{~d}$, during which time their consumption and growth were monitored. Beer was the only carbonated liquid studied, and initially we encountered some problems with excessive drip from the teat of the water bottle. However, once the beer bottle had been open for several days, most of the carbon dioxide disappeared and there were no further difficulties in measuring fluid intake. For this reason, the mean daily intake of beer was calculated from the last $9 \mathrm{~d}$ of the study period, the values from the first $2 \mathrm{~d}$ being discarded. Great care was taken to collect all the spilt fluid, and allowances were made for evaporative losses.

Each animal was counted daily in the whole-body counter and the ${ }^{65} \mathrm{Zn}$ content calculated as a percentage of the original level immediately post-injection, after making corrections for background, counting efficiency and isotope decay.

After $11 \mathrm{~d}$ the animals were killed with a lethal dose of sodium pentobarbitone $(1 \mathrm{ml}$ Euthatal; May \& Baker, Dagenham, Essex). Blood was removed by cardiac puncture for haemoglobin $(\mathrm{Hb})$ estimation by the cyanomethaemoglobin method (Richterich \& Colombo, 1981). The liver was removed for $\mathrm{Fe}$ analysis and the testes for $\mathrm{Zn}$ analysis. Organs were freeze-dried, ground and subsamples ashed at $480^{\circ}$ for $48 \mathrm{~h}$ in silica crucibles. The ash was dissolved in a minimum volume of hot concentrated hydrochloric acid, made up to volume with distilled water, filtered through Whatman no. 542 paper and the Fe or $\mathrm{Zn}$ concentrations measured by atomic absorption spectroscopy (PU9000; Pye Unicam, Cambridge) using certified NBS standards for validation (Office of Standard Reference Materials, Washington DC).

\section{Statistical analysis}

Results were subjected to analysis of variance, and where this showed a treatment effect, approximate $t$ tests were performed using the standard error for differences between means. 
Table 2. Iron and zinc contents of liquids and diet given to rats

\begin{tabular}{lcc}
\hline & Fe $(\mu \mathrm{g} / \mathrm{ml})$ & Zn $(\mu \mathrm{g} / \mathrm{ml})$ \\
\hline Distilled water & 0.04 & 0.20 \\
Beer & 0.14 & 0.03 \\
Cider & 1.67 & 0.21 \\
Wine-water $(0.33: 1, \mathrm{v} / \mathrm{v})$ & 3.29 & 0.24 \\
Whisky-water $(0.1,1, \mathrm{v} / \mathrm{v})$ & 0.10 & 0.35 \\
Ethanol-water $(0.034: 1, \mathrm{v} / \mathrm{v})$ & 0.04 & 0.20 \\
Semi-synthetic diet & $30.5 \mu \mathrm{g} / \mathrm{g}$ & $60.4 \mu \mathrm{g} / \mathrm{g}$ \\
\hline
\end{tabular}

Table 3. Initial and final body-weights, food and liquid intakes $(\mathrm{g} / \mathrm{d})$ of rats given different alcoholic beverages for $11 d$

(Values are means for ten rats/group)

\begin{tabular}{|c|c|c|c|c|c|c|}
\hline Liquid & $\begin{array}{c}\text { Alcohol } \\
(\mathrm{g} / \mathrm{l})\end{array}$ & $\begin{array}{l}\text { Initial } \\
\text { body-wt } \\
\text { (g) }\end{array}$ & $\begin{array}{l}\text { Final } \\
\text { body-wt } \\
\text { (g) }\end{array}$ & $\begin{array}{c}\text { Food } \\
\text { intake } \\
(\mathrm{g})\end{array}$ & $\begin{array}{l}\text { Fluid } \\
\text { intake } \\
\text { (g) }\end{array}$ & $\begin{array}{l}\text { Percentage } \\
\text { of energy } \\
\text { derived from } \\
\text { alcohol } \dagger\end{array}$ \\
\hline Distilled water & 0 & $199 \cdot 3$ & 283.5 & $24 \cdot 0$ & $18 \cdot 0$ & 0 \\
\hline Beer & 31 & $204 \cdot 6$ & $295 \cdot 8$ & $23 \cdot 4$ & $28 \cdot 4^{*}$ & 5.9 \\
\hline Cider & 38 & $198 \cdot 6$ & $277 \cdot 3$ & $21 \cdot 2$ & 16.7 & $4 \cdot 8$ \\
\hline Wine-water $(0.33: 1, v / v)$ & 32 & $201 \cdot 7$ & 284.9 & $22 \cdot 7$ & $19 \cdot 5$ & $4 \cdot 4$ \\
\hline Whisky-water $(0 \cdot 1: 1, \mathrm{v} / \mathrm{v})$ & 32 & $205 \cdot 1$ & $290 \cdot 1$ & $23 \cdot 3$ & 18.9 & $4 \cdot 1$ \\
\hline Ethanol-water $(0.034: 1, \mathrm{v} / \mathrm{v})$ & 34 & $207 \cdot 4$ & $296 \cdot 6$ & $24 \cdot 6$ & $20 \cdot 6$ & $4 \cdot 5$ \\
\hline \multicolumn{7}{|l|}{ Pooled } \\
\hline SEM & & 3.9 & $7 \cdot 0$ & 0.8 & $5 \cdot 5$ & \\
\hline SED & & 5.6 & $9 \cdot 9$ & $1 \cdot 2$ & $2 \cdot 5$ & \\
\hline$F$ & & 0.8 (NS) & $1.2(\mathrm{NS})$ & $2 \cdot 0$ (NS) & $5 \cdot 7(P$ & $<0.01)$ \\
\hline
\end{tabular}

SED, standard error of difference; NS, not significant

* Mean beer intake calculated over last $9 \mathrm{~d}$ of the period.

$\dagger$ Energy value of control diet $16.6 \mathrm{~kJ}(4.2 \mathrm{kcal}) / \mathrm{g}$, and alcohol $29.3 \mathrm{~kJ}(7.0 \mathrm{kcal}) / \mathrm{g}$.

The ${ }^{65} \mathrm{Zn}$ retention values were transformed to $\log _{10}$ values, as described in the Results section, and regression analysis performed on the values for days 6-10 inclusive postinjection. Differences between groups were again tested for using approximate $t$ tests. The relation between ${ }^{65} \mathrm{Zn}$ loss and liver $\mathrm{Fe}$ levels was examined using a Spearman rank correlation coefficient.

\section{RESULTS}

The concentrations of $\mathrm{Fe}$ and $\mathrm{Zn}$ in the diet and in the various fluids are shown in Table 2. All except beer contained a trace of $\mathrm{Zn}$, with whisky containing the highest amount. There was a more marked variation in the $\mathrm{Fe}$ content, the diluted red wine containing the most at $3.3 \mu \mathrm{g} \mathrm{Fe} / \mathrm{ml}$. With a daily intake of $20 \mathrm{ml}$, the wine would provide $66 \mu \mathrm{g} \mathrm{Fe} / \mathrm{rat}$, compared with a daily intake of $700 \mu \mathrm{g}$ from the diet. Therefore the additional Fe (or $\mathrm{Zn}$ ) in the fluids made only a small contribution towards the total intake in terms of absolute amounts.

There were no differences in initial or final body-weights, nor in food intake, between the groups, as shown in Table 3. However, the animals in the beer group drank considerably more than those in the other groups, presumably due to the sensory qualities of beer. 
Table 4. Daily loss of ${ }^{65} \mathrm{Zn} \mathrm{6-10} \mathrm{d} \mathrm{post-injection} \mathrm{and} \mathrm{percentage}{ }^{65} \mathrm{Zn}$ remaining in the body of rats after consumption of different alcoholic beverages for $11 \mathrm{~d}$

(Values are means for ten rats/group)

\begin{tabular}{lcc}
\hline \hline & $\begin{array}{c}{ }^{65} \mathrm{Zn} \text { retained after } 10 \mathrm{~d} \\
\text { (\% of original amount) }\end{array}$ & $\begin{array}{c}\text { Daily }{ }^{65} \mathrm{Zn} \text { loss } \\
\left(\% \text { of total body }{ }^{55} \mathrm{Zn}\right)\end{array}$ \\
\hline Distilled water & $67 \cdot 3^{\mathrm{a}}$ & $2 \cdot 0^{\mathrm{a}}$ \\
Beer & $66 \cdot 7^{\mathrm{a}}$ & $1 \cdot 8^{\mathrm{ac}}$ \\
Cider & $68 \cdot 2^{\mathrm{ab}}$ & $2 \cdot 0^{\mathrm{a}}$ \\
Wine-water $(0 \cdot 33: 1, \mathrm{v} / \mathrm{v})$ & $69 \cdot 6^{\mathrm{b}}$ & $1 \cdot 7^{\mathrm{abc}}$ \\
Whisky-water $(0.1,1, \mathrm{v} / \mathrm{v})$ & $71 \cdot 9^{\mathrm{c}}$ & $1 \cdot 3^{\mathrm{bc}}$ \\
Ethanol-water $(0.034: 1, \mathrm{v} / \mathrm{v})$ & $69 \cdot 6^{\mathrm{b}}$ & $1 \cdot 5^{\mathrm{c}}$ \\
Pooled & $2 \cdot 5$ & 0.5 \\
$\quad$ SEM & $1 \cdot 1$ & $0 \cdot 2$ \\
SED & $6 \cdot 0(P<0.01)$ & $2 \cdot 9(P<0.05)$ \\
\hline
\end{tabular}

SED, standard error of difference.

$a, b, c$, Values in each column with different superscript letters were significantly different $(P<0.05)$.

Table 5. Haemoglobin $(H b)$ concentrations, liver iron and testes zinc of rats given different alchoholic beverages for $11 \mathrm{~d}$

(Values are means for ten rats/group)

\begin{tabular}{|c|c|c|c|c|c|}
\hline Liquid & $\begin{array}{c}\mathrm{Hb} \\
(\mathrm{g} / \mathrm{l})\end{array}$ & $\begin{array}{c}\text { Liver Fe } \\
(\mu \mathrm{g} / \mathrm{g} \text { dry } \mathrm{wt})\end{array}$ & $\begin{array}{l}\text { Total liver } \\
\text { Fe (mg) }\end{array}$ & $\begin{array}{c}\text { Testes } \mathrm{Zn} \\
(\mu \mathrm{g} / \mathrm{g} \text { dry wt) }\end{array}$ & $\begin{array}{l}\text { Total testes } \\
\mathrm{Zn}(\mu \mathrm{g})\end{array}$ \\
\hline Distilled water & 140 & $214^{\mathrm{a}}$ & $1 \cdot 101^{\mathrm{ab}}$ & 160 & 67 \\
\hline Beer & 139 & $221^{\mathrm{a}}$ & $1 \cdot 170^{\mathrm{abc}}$ & 148 & 62 \\
\hline Cider & 140 & $200^{\mathrm{a}}$ & $0.956^{\mathrm{a}}$ & 154 & 64 \\
\hline $\begin{array}{l}\text { Wine-water } \\
(0 \cdot 33: 1, \mathrm{v} / \mathrm{v})\end{array}$ & 139 & $256^{\mathrm{b}}$ & $1.24 I^{\text {be }}$ & 156 & 66 \\
\hline $\begin{array}{r}\text { Whisky-water } \\
(0.1: 1, \mathrm{v} / \mathrm{v})\end{array}$ & 141 & $262^{b}$ & $1.313^{b c}$ & 152 & 66 \\
\hline $\begin{array}{l}\text { Ethanol-water } \\
(0.034: 1, \mathrm{v} / \mathrm{v})\end{array}$ & 138 & $268^{b}$ & $1 \cdot 373^{\mathrm{C}}$ & 152 & 67 \\
\hline \multicolumn{6}{|l|}{ Pooled } \\
\hline SEM & $1 \cdot 7$ & 11 & 0.077 & 5 & 2 \\
\hline SED & $2 \cdot 5$ & 16 & $0 \cdot 109$ & 7 & 3 \\
\hline$F$ & 0.4 (NS) & $6.3(P<0.01)$ & $3.9(P<0.01)$ & 0.8 (NS) & $1 \cdot 0(\mathrm{NS})$ \\
\hline
\end{tabular}

a,h.c. Values in each column with different superscript letters were significantly different $(P<0.05)$. SED, standard error of difference; NS, not significant.

The percentage loss of injected ${ }^{65} \mathrm{Zn}$ followed an exponential decay curve, and in order to compare rates between the groups the amount of $\mathrm{Zn}$ retained (expressed as a percentage of the initial value) was transformed to the $\log _{10}$ value and plotted against time. The relation was linear between days 6 and 10 (inclusive) post-injection, as demonstrated by regression analysis, when the mean percentage variance accounted for was 94-1 (SEM 1.0). There was a small but significant effect of type of liquid consumed on the amount of ${ }^{65} \mathrm{Zn}$ lost during days 6-10 post-injection, and on the amount of ${ }^{65} \mathrm{Zn}$ remaining after $10 \mathrm{~d}$, as shown in Table 4 . The most obvious difference was in the group given whisky. These animals had a smaller daily loss of ${ }^{65} \mathrm{Zn}$ than those given distilled water, beer or cider. The ethanol group also exhibited a lower rate of loss of ${ }^{65} \mathrm{Zn}$, compared with the distilled-water 
group. The differences in rate of loss of ${ }^{65} \mathrm{Zn}$ resulted in differences in ${ }^{65} \mathrm{Zn}$ retention $10 \mathrm{~d}$ post-injection (when expressed as a percentage of the initial value) with the whisky group retaining the most ${ }^{65} \mathrm{Zn}$, followed by the ethanol and wine groups.

Blood $\mathrm{Hb}$ values, liver $\mathrm{Fe}$ and testes $\mathrm{Zn}$ are given in Table 5. The liver and testes weights and moisture contents were similar in all groups. Although there were no differences in blood $\mathrm{Hb}$ levels, the different fluids had an effect on the Fe concentration and total $\mathrm{Fe}$ content of the liver. Rats given cider had the lowest levels, followed by distilled water then beer. Those given wine, whisky and ethanol had higher Fe concentrations, ethanol having the greatest effect, despite the fact that it contributed no more $\mathrm{Fe}$ than distilled water. Furthermore, there was an inverse correlation $(P<0.05)$ between liver Fe level and daily ${ }^{65} \mathrm{Zn}$ loss $(r$ 0.93). The $\mathrm{Zn}$ content of the testes was unaffected by the type of fluid consumed.

\section{DISCUSSION}

Alcoholism had been associated with $\mathrm{Zn}$ deficiency (Vallee et al. 1957; Sullivan \& Lankford, 1965), and apart from inadequate $\mathrm{Zn}$ intake, one possible explanation for this phenomenon would be an accelerated loss of $\mathrm{Zn}$ from the body. Prolonged hyperzincuria, if unaccompanied by any $\mathrm{Zn}$-conserving mechanisms, may well lead to $\mathrm{Zn}$ depletion. Moderate intakes of alcohol have been reported to cause increased urinary $\mathrm{Zn}$ excretion in normal subjects (Carey et al. 1971) and patients with alcoholic cirrhosis (Kahn et al. 1965; Mills et al. 1983), and rats fed on Zn-deficient diets (Ahmed \& Russell, 1982), but there are also reports demonstrating that alcohol consumption does not affect urinary $\mathrm{Zn}$ loss (Sullivan, 1962; Helwig et al. 1966). The present study was undertaken to study the effect of consuming small amounts ( $4-6 \%$ of total energy intake) of various alcoholic beverages and ethanol on loss of endogenous $\mathrm{Zn}$, labelled with ${ }^{85} \mathrm{Zn}$, from the body. Contrary to expectation, there was, in fact, a small but significant decrease in $\mathrm{Zn}$ loss in animals given wine, whisky or ethanol when compared with distilled water. Beer and cider had no effect on $\mathrm{Zn}$ retention. After $11 \mathrm{~d}$ of alcohol consumption, there were no differences in $\mathbf{Z n}$ concentration or total $\mathrm{Zn}$ in the testes. This tissue was selected as being very sensitive to changes in dietary $\mathrm{Zn}$ levels (Prasad et al. 1967) and, therefore, should reflect any major changes in $\mathrm{Zn}$ metabolism. For example, Ahmed \& Russell (1982) found that testes were the first tissue to show a reduction in $\mathrm{Zn}$ concentration in rats fed on a $\mathrm{Zn}$-deficient liquid diet containing ethanol, when compared with control animals. In the present experiment the small differences in whole-body daily ${ }^{65} \mathrm{Zn}$ loss were obviously not great enough to affect the levels of $\mathrm{Zn}$ in this tissue over the $11 \mathrm{~d}$ experimental period, but further work is required to determine whether changes would occur over a longer period of modest alcohol consumption.

The results we obtained with rats lend support to the findings of Helwig et al. (1966) and Sullivan (1962) that alcohol per se does not result in increased urinary $\mathrm{Zn}$ excretion in normal subjects, but that alcohol-induced hepatic damage is a major determinant of urinary $\mathrm{Zn}$ excretion, since hepatic disease is accompanied by increases in urinary $\mathrm{Zn}$ excretion. The different responses to alcohol consumption reported in the literature probably relate to the degree of hepatic disturbance, as influenced by individual susceptibility and the level of alcoholic consumption.

Lower $\mathrm{Zn}$ absorption might also explain the effect of alcohol on $\mathrm{Zn}$ status observed in some studies (Vallee et al. 1957; Sullivan \& Lankford, 1965). This could be caused by a direct reduction in the amount of $\mathrm{Zn}$ available for absorption or be related to intestinal epithelial changes that occur with alcohol consumption (Hillman, 1975). Using a dual-label technique, Dinsmore et al. (1985) showed that chronic alcoholics absorbed less $\mathrm{Zn}$ (from $9 \mu \mathrm{mol} \mathrm{ZnCl}{ }_{2}$ labelled with $37 \mathrm{KBq}{ }^{65} \mathrm{Zn}$ ) than non-alcoholics, which points to alcoholrelated changes in gut function rather than lumen interactions between ethanol and $\mathrm{Zn}$. 
Antonson \& Vanderhoof (1983) have demonstrated by perfusion in vivo that rats given a diet containing $36 \%$ of the energy as ethanol for 1 month had significantly reduced $\mathrm{Zn}$ absorption in the ileum. It has been suggested that the first step in diminished intestinal absorption of $\mathrm{Zn}$ in alcoholism is reduced binding to high-molecular-weight jejunal proteins (Silverman \& Rivlin, 1982). In the present study, three of the groups of rats consuming alcohol excreted less ${ }^{65} \mathrm{Zn}$ than the controls, which may well be a direct effect of reduced absorption of $\mathrm{Zn}$ from the diet; we have already demonstrated the rapid response made by rats to changes in dietary $\mathrm{Zn}$ levels whereby $\mathrm{Zn}$ is conserved when $\mathrm{Zn}$ intake is limited (Fairweather-Tait et al. 1985). It is possible, therefore, that in the absence of hepatic damage, any adverse effects of alcohol on $\mathrm{Zn}$ status are mediated through reduced absorption from the diet rather than increased elimination from the body.

The present study also showed that consumption of wine, whisky and ethanol resulted in higher liver Fe concentrations, whereas beer and cider had no effect on Fe status. The group given cider had the lowest total liver Fe content and the group given ethanol had the highest. It has been known for some time that alcoholics have greater than normal $\mathrm{Fe}$ stores, which has been linked to the observed enhancement in absorption of ferric-Fe in the presence of alcohol in normal subjects (Charlton et al. 1964) and ferrous-Fe in Fe-deficient subjects (Sorensen, 1966). However, it has been reported that in rats the absorption of $\mathrm{Fe}$ from a single dose of ${ }^{59} \mathrm{Fe}$ intrinsically labelled wine was similar to the absorption from the same amount of $\mathrm{Fe}$ as ferrous sulphate in water or other alcoholic beverages, including beer, whisky, gin and bourbon (MacDonald \& Pechet, 1964). Similar observations have been made in our laboratory (unpublished results) which suggest that alcohol increases $\mathrm{Fe}$ absorption from ferric- but not ferrous- $\mathrm{Fe}$ in Fe-replete rats. Most of the Fe consumed by the animals in the present experiment was in the form of ferrous sulphate, yet liver Fe was raised in animals given wine, whisky and ethanol. From the present findings it might be inferred that these substances had caused tissue redistribution of Fe. However, in view of the fact that $\mathrm{Hb}$ levels (and hence erythropoeisis) were similar between all groups, the most likely explanation for the higher liver Fe levels in rats given wine, whisky and ethanol would be an increase in $\mathrm{Fe}$ absorption from the diet. The fact that the same level of alcohol in beer or cider did not provoke the same effect suggests that they contained antagonistic substances such as tannins that negated the Fe-absorption-enhancing effect of ethanol (Gillooly et al. 1984). It was interesting to note that animals with the lowest loss of ${ }^{65} \mathrm{Zn}$ had the highest liver Fe levels, which suggests an interaction in the intestinal lumen that somehow modifies absorption.

It is apparent from the present study that some alcoholic beverages and ethanol alone can affect $\mathrm{Zn}$ and $\mathrm{Fe}$ metabolism. Findings presented here demonstrate that ${ }^{65} \mathrm{Zn}$ loss from mobilizable endogenous pools is reduced with alcohol consumption and Fe absorption is increased. The response to alcoholic drinks is dependent on the type of beverage consumed, presumably because of other substances present in the fluids. It would appear from the results of the present study that certain components of beer and cider have a modifying effect on both ${ }^{65} \mathrm{Zn}$ loss and liver $\mathrm{Fe}$ accumulation.

The authors thank Ms Lisa Symss for the atomic absorption spectroscopy measurements, Mr A. J. A. Wright for technical assistance, and Mrs Jacqui Cooke for help with the animals.

Ahmed, S. B. \& Russell, R. M. (1982). Journal of Laboratory and Clinical Medicine 100, 211-217.

Antonson, D. L. \& Vanderhoof, J. A. (1983). Digestive Diseases and Sciences 28, 604-608.

Carey, M. A., Jones, J. D. \& Gastineau, C. F. (1971). Journal of American Medical Association 216, $1766-1769$.

Charlton, R. W., Jacobs, P., Seftel, H. \& Bothwell, T. H. (1964). British Medical Journal ii, 1427-1429. 
Dinsmore, W., Callender, M. E., McMaster, D., Todd, S. J. \& Love, A. H. G. (1985). Digestion 32, $238-242$.

Fairweather-Tait, S. J. \& Wright, A. J. A. (1984). British Journal of Nutrition 51, 185-191.

Fairweather-Tait, S. J., Wright, A. J. A., Cooke, J. \& Franklin, J. (1985). British Journal of Nutrition 54, 401-413.

Gillooly, M., Bothwell, T. H., Charlton, R. W., Torrance, J. D., Bezwoda, W. R., MacPhail, A. P., Derman, D. P., Novelli, L., Morrall, P. \& Mayet, F. (1984). British Journal of Nutrition 51, 37-46.

Helwig, H. L., Hoffer, E. M., Thielen, W. C., Alcocer, A. E., Hotelling, D. R., Rogers, W. H. \& Lench, J. (1966). American Journal of Clinical Pathology 45, 156-159.

Hillman, R. S. (1975). Annals of the New York Academy of Science 252, 297-306.

Kahn, A. M., Helwig, H. L., Redeker, A. G. \& Reynolds, T. B. (1965). American Journal of Clinical Pathology 44, $426-435$

McDonald, J. T. \& Margen, S. (1980). American Journal of Clinical Nutrition 33, 1096-1102.

MacDonald, R. A. \& Pechet, G. S. (1964). Proceedings of the Society of Experimental Biology and Medicine 117, 54-56.

Mills, P. R., Fell, G. S., Bessent, R. G., Nelson, L. M. \& Russell, R. I. (1983). Clinical Science 64, 527-535.

Prasad, A. S., Oberleas, D., Wolf, P. \& Horwitz, J. P. (1967). Journal of Clinical Investigation 46, 549-557.

Richterich, R. \& Colombo, J. P. (1981). Clinical Chemistry, pp. 543-546. Chichester: John Wiley \& Sons.

Silverman, B. \& Rivlin, R. S. (1982). Journal of Nutrition 112, 744-749.

Sorensen, E. W. (1966). Acta Medica Scandinavica 180, 24I-244.

Sullivan, J. F. (1962). Quarterly Journal of Studies on Alcohol 23, 216-220.

Sullivan, J. F. \& Lankford, H. G. (1965). American Journal of Clinical Nutrition 17, 57-63.

Vallee, B. L., Wacher, W. E., Bartholomay, A. F. \& Hoch, F. L. (1957). New England Journal of Medicine 257, 1055-1065. 